\title{
High Resolution Computed Tomography Finding in 552 Patients with Symptomatic COVID-19: First Report from North of Iran
}

\section{Hadi Majidi}

Department of Radiology, Faculty of Medicine, Mazandaran University of Medical Sciences, Sari, Iran. Elham-Sadat Bani-Mostafavi

Department of Radiology, Faculty of Medicine, Mazandaran University of Medical Sciences, Sari, Iran.

\section{Zahra Mardanshahi}

Department of Radiology, Faculty of Medicine, Mazandaran University of Medical Sciences, Sari, Iran.

\section{Farnaz Godazandeh}

Department of Radiology, Faculty of Medicine, Mazandaran University of Medical Sciences, Sari, Iran.

\section{Roya Gasemian}

Department of Radiology, Faculty of Medicine, Mazandaran University of Medical Sciences, Sari, Iran.

\section{Keyvan Heydari}

Student Research Committee, Mazandaran University of Medical Sciences, Sari, Iran

\section{Reza Alizadeh-Navaei ( $\nabla$ reza_nava@yahoo.com )}

Gastrointestinal Cancer Research Center, Mazandaran University of Medical Sciences, Sari, Iran https://orcid.org/0000-0003-0580-000X

\section{Research Article}

Keywords: Corona virus 2019, Ground glass, Peripheral distribution, Pleural effusion

Posted Date: November 6th, 2020

DOI: https://doi.org/10.21203/rs.3.rs-25817/v2

License: (c) (1) This work is licensed under a Creative Commons Attribution 4.0 International License. Read Full License

Version of Record: A version of this preprint was published at Emergency Radiology on July 13th, 2020. See the published version at https://doi.org/10.1007/s10140-020-01819-9. 


\title{
High-resolution computed tomography finding in 552 patients with symptomatic COVID-19: first report from north of Iran
}

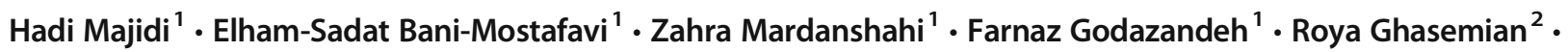 \\ Keyvan Heydari ${ }^{3} \cdot$ Reza Alizadeh-Navaei $^{4}$ (D)
}

Received: 14 April 2020 / Accepted: 6 July 2020

(C) American Society of Emergency Radiology 2020

\begin{abstract}
Purpose Due to the emergence of the new coronavirus 2019 and the lack of sufficient information about infected patients, this study was conducted to investigate the chest high-resolution computed tomography (HRCT) findings of patients infected with the new coronavirus 2019.

Methods This cross-sectional study was performed on COVID-19 patients referred to Medical Imaging Centers of Sari, Mazandaran, Iran, on March 2020 for computed tomography (CT) scan. Symptomatic patients were referred to the Medical Imaging Center for diagnosis confirmation through CT scan. In addition to age and sex, HRCT findings were collected from the picture archiving and communication system (PACS) for further evaluations.

Results Out of 552 patients with mean age of $51.2 \pm 14.8$ years, the male/female ratio was 1.38 to 1 . The most common expressive findings in patients were ground-glass opacity (GGO) (87.3\%), peripheral distribution (82.4\%), and posterior distribution $(81.5 \%)$. The most conflicting findings in patients were pleural effusion $(7.6 \%)$, peribronchovascular distribution $(7.6 \%)$, and lymphadenopathy $(5.1 \%)$. The peripheral distribution $(p=0.034)$, round opacities $(p=0.02)$, single lobe $(p=0.003)$, and pleural effusion $(p=0.037)$ were significant in people under and over 50 years of age.

Conclusion In summary, the present study indicated that in addition to GGO, peripheral distribution findings could be a vital diagnostic choice in COVID-19 patients.
\end{abstract}

Keywords Coronavirus 2019 · Ground glass · Peripheral distribution · Pleural effusion

Reza Alizadeh-Navaei

reza_nava@yahoo.com

1 Department of Radiology, Faculty of Medicine, Mazandaran University of Medical Sciences, Sari, Iran

2 Antimicrobial Resistance Research Center, Mazandaran University of Medical Sciences, Sari, Iran

3 Student Research Committee, Mazandaran University of Medical Sciences, Sari, Iran

4 Gastrointestinal Cancer Research Center, Non-communicable Diseases Institute, Mazandaran University of Medical Sciences, Sari, Iran

\section{Introduction}

The COVID-19 is a novel heat-sensitive coronavirus. Based on evolutionary research, it has been found that the virus has originated from animals like bats, rodents, and birds [1]. In early December 2019, the first cases of pneumonia of unknown etiology were observed in Wuhan, the capital of Hubei Province in China [2]. The pathogen, which was a single-stranded enveloped coronavirus RNA [3], was called acute respiratory syndrome coronavirus 2 (SARS-CoV-2), and the course of the disease caused by the virus is pathologically somewhat similar to that of severe acute respiratory syndrome (SARS) [4]. So far, seven types of coronaviruses have been identified that can infect humans [4-6]. 
Viruses that cause severe acute respiratory syndrome (SARS), Middle East respiratory syndrome (MERS), and the coronavirus disease (COVID-19) have zoonotic origins [6] and are transmitted from person to person [7]. About $13.9 \%$ of patients with COVID-19 died, and about half of those who visited hospitals were discharged after receiving the necessary treatment [8]. According to the study by Guan et al., 1099 patients in 552 hospitals with COVID-19 and an average age of 47 years were examined. Common manifestations of the virus include fever above $37.5{ }^{\circ} \mathrm{C}(56.2 \%)$, cough (67.8\%), and lymphocytopenia (83.2\%) [9]. According to several studies that examined the imaging findings of COVID-19 patients, 69 to $89 \%$ of the patients had positive chest CT findings [10,11]. Ground-glass opacity (GGO) is frequently observed which has been reported in most studies $[12,13]$. Radiological evaluation often plays a key role in confirming the diagnosis of COVID-19 in suspected cases when test kits are not available. Given the recency of the virus and the lack of sufficient information on patients involved in COVID-19 in Iran, during this study, the imaging findings of patients with COVID-19 were examined in Mazandaran province, located in the north of Iran.

\section{Materials and methods}

This cross-sectional study was conducted in March 2020 on symptomatic patients who visited the imaging centers of Sari during the coronavirus epidemic. The study population were patients with high clinical suspicion who performed a CT scan because of limited laboratory testing in Iran to confirm the diagnosis and treatment. The
CT scanner was a Somatom Emotion 16 by Siemens with a 16-slice configuration. The high-resolution computed tomography (HRCT) in axial sections was used without the contrast material with section thickness of $2 \mathrm{~mm}$. The low-dose protocol (low-dose computed tomography) with radiation conditions of $\mathrm{Kvp}=100$ $120, \mathrm{mAs}=50-100$, and pitch $=1 \mathrm{~mm}$ was used. The patient was supine in the CT scanner with his/her arm above their head. CT scanning started from the apex to the lowest part of the lungs in a deep inspiration.

The required information, including demographic data such as age, gender, and HRCT results, was collected and recorded in a researcher-made checklist by four radiologists using the PACS system.

Data were analyzed in SPSS 20 using $t$ test, chi-square, and Fisher's exact tests, and a $p<0.05$ was considered as significant. Finally, due to the very different sample size in the literature, meta-analysis was undertaken using random effect method and Stata software to better compare the reported percentages.

\section{Results}

The study was conducted on 552 symptomatic patients with clinical suspicion who visited for HRCT. The mean age of participants was $51.2 \pm 14.8$ years, in the range of 16 to 99 years, and the age group of 50 to 59 years with the relative frequency of $25.4 \%$ showed the highest involvement (Fig. 1). In this study, 317 males $(57.4 \%)$ and 235 females $(42.6 \%)$ participated with a male/female sex ratio of 1.38 .

The most common presented findings in patients were ground glass opacity (482 cases, $87.3 \%$ ), peripheral distribution (455
Fig. 1 Age distribution of patients with coronavirus 2019

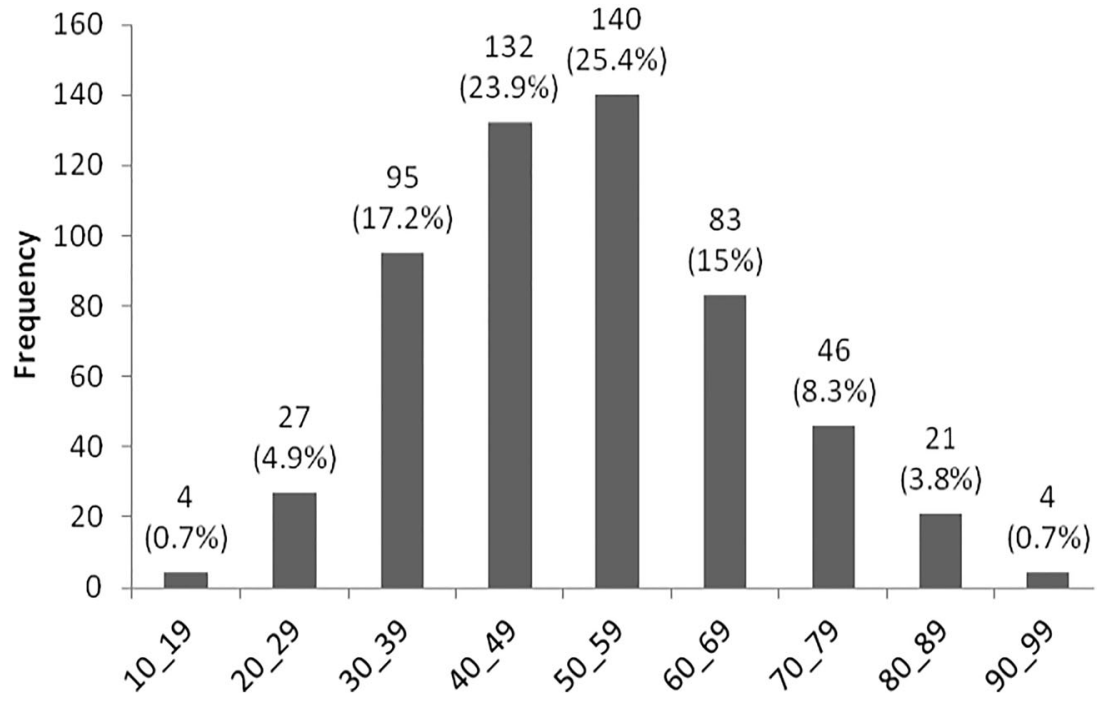


Table 1 Presented findings in HR CT scan of symptomatic patients infected with coronavirus 2019

\begin{tabular}{|c|c|c|c|c|c|c|c|}
\hline Findings & $\begin{array}{l}\text { Total } \\
n=552 \\
\text { Frequency }(\%)\end{array}$ & $\begin{array}{l}\text { Female } \\
n=235 \\
\text { Frequency }(\%)\end{array}$ & $\begin{array}{l}\text { Male } \\
n=317 \\
\text { Frequency }(\%)\end{array}$ & $p$ value & $\begin{array}{l}\text { Age } \leq 50 \\
n=271 \\
\text { Frequency }(\%)\end{array}$ & $\begin{array}{l}\text { Age }>50 \\
n=281 \\
\text { Frequency }(\%)\end{array}$ & $p$ value \\
\hline Ground glass & $482(87.3)$ & $205(87.2)$ & $277(87.4)$ & 1 & $239(88.2)$ & $243(86.5)$ & 0.609 \\
\hline Acinar shadows & $261(47.3)$ & $118(50.2)$ & $143(45.1)$ & 0.262 & $127(46.9)$ & $134(47.7)$ & 0.865 \\
\hline \multicolumn{8}{|c|}{ Bailateral/multilobar involvement } \\
\hline $\begin{array}{l}\text { Minimal } \\
\text { Mild }\end{array}$ & $\begin{array}{l}127(23) \\
152(27.5)\end{array}$ & $\begin{array}{l}65(27.7) \\
56(23.8)\end{array}$ & $\begin{array}{l}62(19.6) \\
96(30.3)\end{array}$ & \multirow[t]{3}{*}{0.186} & $\begin{array}{l}76(28) \\
75(27.7)\end{array}$ & $\begin{array}{l}51(18.1) \\
77(27.4)\end{array}$ & \multirow[t]{3}{*}{0.053} \\
\hline Moderate & $184(33.3)$ & $78(33.2)$ & $106(33.4)$ & & $83(30.6)$ & $101(35.9)$ & \\
\hline Severe & $44(8)$ & $17(7.2)$ & $27(8.5)$ & & $17(6.3)$ & $27(9.6)$ & \\
\hline Single lobe & $100(18.1)$ & $45(19.1)$ & $55(17.4)$ & 0.655 & $63(23.2)$ & $37(13.2)$ & 0.003 \\
\hline Peripheral distribution & $455(82.4)$ & $192(81.7)$ & $263(83)$ & 0.735 & $233(86)$ & $222(79)$ & 0.034 \\
\hline Central distribution & $280(50.7)$ & $111(47.2)$ & $169(53.3)$ & 0.169 & $131(48.3)$ & $149(53)$ & 0.307 \\
\hline Posterior distribution & $450(81.5)$ & $194(82.6)$ & $256(80.8)$ & 0.658 & $222(81.9)$ & $228(81.1)$ & 0.827 \\
\hline Anterior distribution & $325(58.9)$ & $136(59.6)$ & $189(58.9)$ & 0.727 & $153(56.5)$ & $172(61.2)$ & 0.262 \\
\hline Round opacities & $89(16.1)$ & $43(18.3)$ & $46(14.5)$ & 0.243 & $54(19.9)$ & $35(12.5)$ & 0.02 \\
\hline linear opacities & $41(7.4)$ & $17(7.2)$ & $24(7.6)$ & 1 & $14(5.2)$ & $27(9.6)$ & 0.052 \\
\hline Crazy paving & $8(1.4)$ & $2(0.9)$ & $6(1.9)$ & 0.477 & $2(0.7)$ & $6(2.1)$ & 0.286 \\
\hline Reversed halo & $9(1.6)$ & $4(1.7)$ & $5(1.6)$ & 1 & $6(2.2)$ & $3(1.1)$ & 0.332 \\
\hline
\end{tabular}



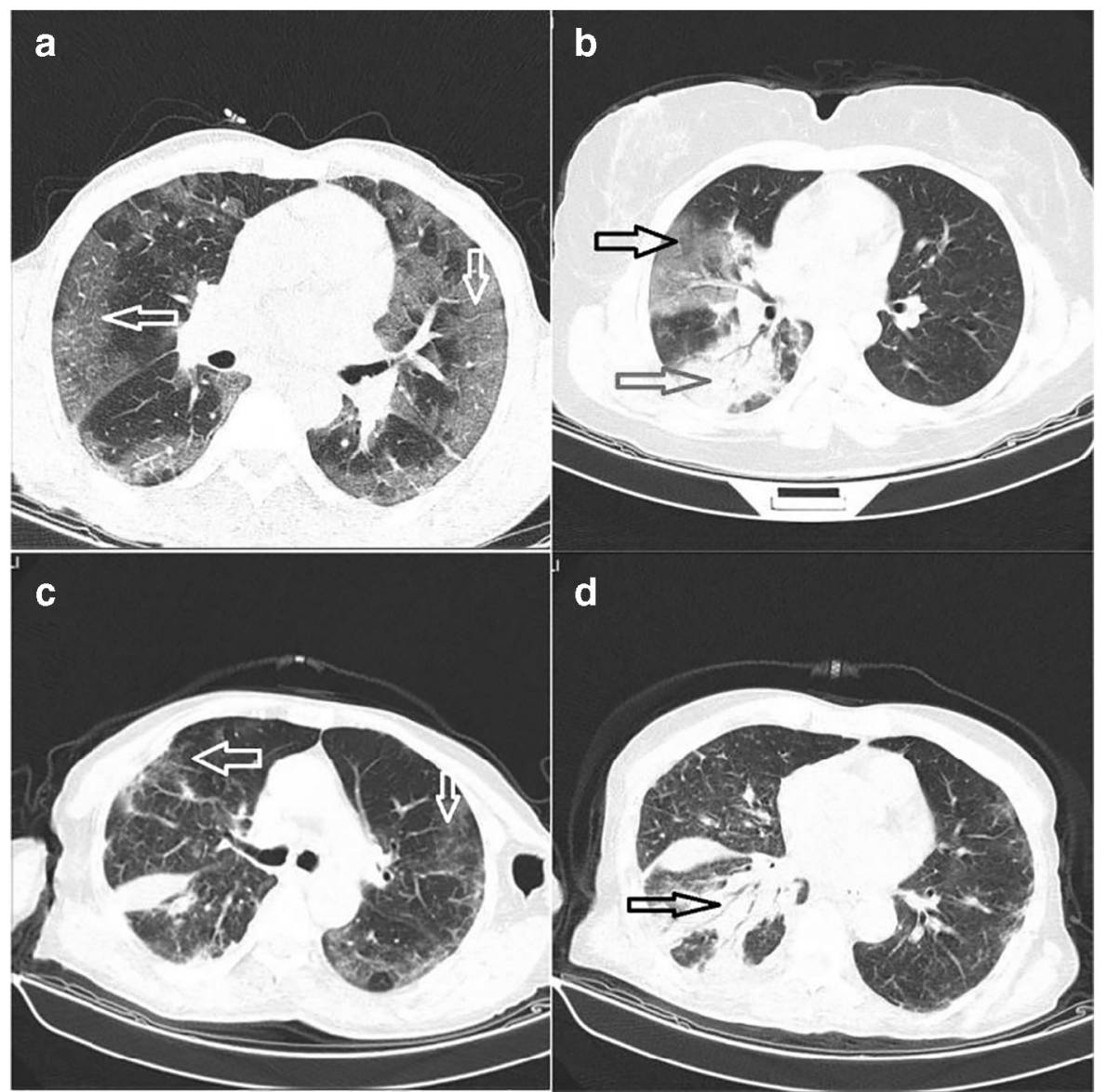

d
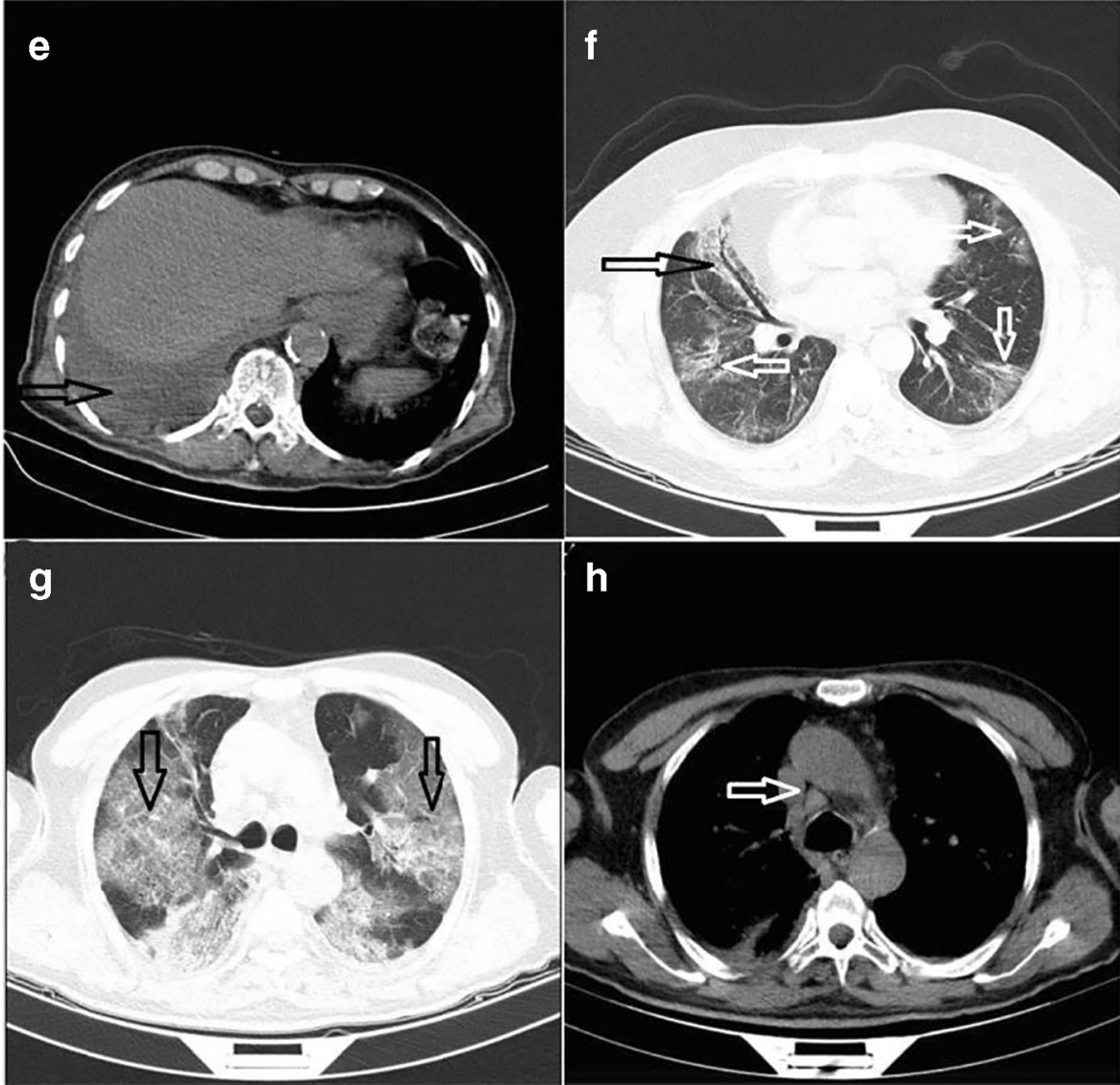
Fig. 2 a Bilateral and anterior to posterior peripheral ground glass opacities (white arrows). b Ground glass opacity in upper lobe (black arrow) and consolidation in lower lobe of right lung (red arrow). c Bilateral and peripheral ground glass opacities (white arrows). d Consolidation in right lower lobe (black arrow). e Right-sided pleural effusion (red arrow). f Bilateral and anterior to posterior peripheral ground glass opacities (white arrows) with peribronchovascular distribution in right middle lobe (black arrow). $\mathrm{g}$ Bilateral and anterior to posterior peripheral ground glass opacities (black arrows). h Small lymphadenopathies in middle mediastinum (white arrow)

cases, $82.4 \%$ ), posterior distribution (450 cases, $81.5 \%$ ), and anterior distribution (325 cases, 58.9\%) (Table 1 and Fig. 2). Figure 2 shows the CT scan finding of 5 patients as examples. There was no significant difference between patients of both genders in the distribution of presented findings. Peripheral distribution (86\% vs 79\%, $p=0.034$ ) along with the findings of round opacity $(19.5 \%$ vs $12.5 \%, p=0.02)$ and single lobe ( $23.2 \%$ vs $13.2 \%, p=0.003)$ was significantly higher in patients under 50 compared to those over 50 (Table 1).

The most common inconsistent findings in the study population were pleural effusion (42 cases, 7.6\%), peribronchovascular distribution (42 cases, 7.6\%), and lymphadenopathy (28 cases, $5.1 \%$ ) (Table 2 and Fig. 2). There was no significant difference between patients of both genders in the distribution of inconsistent findings. The age distribution of inconsistent findings indicated that pleural effusion was significantly higher $(p=0.037)$ in patients over 50 years of age (28 cases, 10\%) compared to those under 50 (14 cases, 5.2\%) (Table 2).

\section{Discussion}

CT images with yielded $98 \%$ sensitivity play an important role in the diagnosis and evaluation of COVID-19 and can be used as a standard method for rapid diagnosis of COVID-19 to manage patients [4-16]. The present study was conducted on 552 patients with clinical suspicion who referred for HRCT and had signs of involvement in the CT images. The most common presented findings in patients were ground glass opacity, peripheral distribution, and posterior distribution. The prevalence of ground glass opacity in the study population was $87.3 \%$, which varied from 41 to $100 \%$ in other studies [9, 14, 17-28], and the prevalence of this finding was $67 \%$ given the difference in sample size in different studies and conducting the meta-analysis on these studies (Table 3). Peripheral distribution was the second most common finding in $82.4 \%$ of the study population. The prevalence of this finding in other studies ranged from 33 to $98 \%$ [15-21, 23, 25, 27, 28]. The meta-analysis conducted on the present study and other studies presented the peripheral distribution with $79 \%$ prevalence as the most common CT finding in these patients (Table 3 ).

The most common inconsistent findings in patients were pleural effusion, peribronchovascular distribution, and lymphadenopathy. Pleural effusion was $7.6 \%$ in the present study, which ranged between 2 and $9.7 \%$ in other studies, and the combination of the results of the present study and other studies estimated a $7 \%$ pleural effusion (Table 3). Lymphadenopathy in the CT scan was $5.1 \%$ higher than the value reported by other studies, such that this finding was not observed in two studies $[15,27]$ while it was $2.7 \%$ in one study [17] and $6 \%$ in another study. The total estimation was $4 \%$ (Table 3).

A halo sign of $1.6 \%$ was an uncommon finding in the present study, while other studies reported 11.1 to $64 \%[15,20,29]$. The cumulative rate of the present study and other studies estimated a $41 \%$ rate of halo sign (Table 3 ). In addition, a similar situation occurred with crazy-paving as an uncommon finding in the present study which varied from $1.4 \%$ in this study to $12-89 \%$ in other studies [18-20,24]. The meta-analysis of the present study and other studies provided a rate of $32 \%$ for this finding.

Most CT findings in the present study showed no significant difference between genders and age groups, except for peripheral distribution, round opacities, single lobe, and pleural effusion, which showed a significant difference between the age groups under and over 50 years old. In a study by Song et al., ground glass opacity and consolidative opacities were significantly different between age groups under and over 50 years old [28].

Table 2 Inconsistent findings in HR CT scan of symptomatic patients infected with coronavirus 2019

\begin{tabular}{|c|c|c|c|c|c|c|c|}
\hline Findings & $\begin{array}{l}\text { Total } \\
n=552 \\
\text { Frequency }(\%)\end{array}$ & $\begin{array}{l}\text { Female } \\
n=235 \\
\text { Frequency }(\%)\end{array}$ & $\begin{array}{l}\text { Male } \\
n=317 \\
\text { Frequency }(\%)\end{array}$ & $p$ value & $\begin{array}{l}\text { Age } \leq 50 \\
n=271 \\
\text { Frequency }(\%)\end{array}$ & $\begin{array}{l}\text { Age }>50 \\
n=281 \\
\text { Frequency }(\%)\end{array}$ & $p$ value \\
\hline Tree-in-bud capacities & $7(1.3)$ & $2(0.9)$ & $5(1.6)$ & 0.704 & $2(0.7)$ & $5(1.8)$ & 0.451 \\
\hline Centrilobular distribution & $5(0.9)$ & $2(0.9)$ & $3(0.9)$ & 1 & $1(0.4)$ & $4(1.4)$ & 0.373 \\
\hline Peribronchovascular distribution & $42(7.6)$ & $22(9.4)$ & $20(6.3)$ & 0.196 & $19(7)$ & $23(8.2)$ & 0.633 \\
\hline Predominantly nodular opacities & $12(2.2)$ & $7(3)$ & $5(1.6)$ & 0.377 & $5(1.8)$ & $7(2.5)$ & 0.772 \\
\hline Cavitation & $6(1.1)$ & $2(0.9)$ & $4(1.3)$ & 1 & $1(0.4)$ & $5(1.8)$ & 0.217 \\
\hline Lymphadenopathy & $28(5.1)$ & $15(6.4)$ & $13(4.1)$ & 0.244 & $11(4.1)$ & $17(6)$ & 0.335 \\
\hline Pleural effusion & $42(7.6)$ & $21(8.9)$ & $21(6.6)$ & 0.333 & $14(5.2)$ & $28(10)$ & 0.037 \\
\hline
\end{tabular}


Table 3 CT scan findings in different study and pooled estimation of these findings

\begin{tabular}{|c|c|c|c|c|c|c|c|}
\hline Author & $\begin{array}{l}\text { Sample } \\
\text { size }\end{array}$ & $\begin{array}{l}\text { Ground- } \\
\text { glass } \\
\text { opacity }\end{array}$ & $\begin{array}{l}\text { Peripheral } \\
\text { distribution }\end{array}$ & $\begin{array}{l}\text { Pleural } \\
\text { effusion }\end{array}$ & Lymphadenopathy & Halo sign & $\begin{array}{l}\text { Crazy- } \\
\text { paving }\end{array}$ \\
\hline Guan, WJ [9] & 975 & 56.4 & & & & & \\
\hline $\mathrm{Wu}, \mathrm{J}[14]$ & 80 & 91.0 & & & & & \\
\hline $\mathrm{Li}, \mathrm{Y}[15]$ & 51 & & 90.2 & 2.0 & 0.0 & 21.5 & \\
\hline Bai, HX [17] & 424 & 91.0 & 80.0 & 4.1 & 2.7 & & \\
\hline Chung, M [18] & 21 & 87.0 & 33.0 & & & & 19.0 \\
\hline Guan, CS [19] & 47 & 100.0 & 93.6 & & & & 89.4 \\
\hline Han, R [20] & 108 & 60.0 & 90.0 & & & 64.0 & 40.0 \\
\hline Liu, H [21] & 59 & 72.0 & 98.0 & & & & \\
\hline Liu, KC [22] & 73 & 59.0 & & 3.4 & & & \\
\hline Shi, H [23] & 81 & 65.0 & 54.0 & & & & \\
\hline $\mathrm{Xu}, \mathrm{X}[24]$ & 90 & 72.0 & & & & & 12.0 \\
\hline Zhao, W [25] & 101 & 86.1 & 87.1 & & & & \\
\hline Zhu, W [26] & 32 & 47.0 & & & & & \\
\hline $\mathrm{Li}, \mathrm{K}[27]$ & 56 & 80.4 & 87.5 & 8.9 & 0.0 & & \\
\hline Song, F [28] & 51 & 77 & & 8 & 6 & & \\
\hline Zhou, S [29] & 62 & & 77.4 & 9.7 & & & \\
\hline Yoon, SH [30] & 9 & & & & & 11.1 & \\
\hline Majidi, H (Present) & 552 & 87.3 & 82.4 & 7.6 & 5.1 & 1.6 & 1.4 \\
\hline $\begin{array}{l}\text { Pooled estimation } \\
\text { (CI95\%) with meta-analysis }\end{array}$ & & $67(58-76)$ & $79(66-92)$ & $7(-24-39)$ & $4(-26-35)$ & $41(11-72)$ & $32(4-59)$ \\
\hline
\end{tabular}

Mean age of participants was $51.2 \pm 14.8$ years. The male/ female sex ratio was 1.38 . Similar to the results of the present study, in a study conducted on 1099 patients in China, the mean age of patients was 47 years, and the same sex ratio was observed [9].

The present study utilized an acceptable sample size which is one of the strengths of the present study. One of the weaknesses of the study is the lack of diagnostic confirmation by RT-PCR test, which was not possible for all patients due to the epidemic that occurred and the limited number of tests in Iran at the beginning of the epidemic. Other limitations of the study include the lack of a standard reporting format for the chest CT scans in these patients.

\section{Conclusion}

Compared to other studies, the findings of the present study reported the peripheral distribution and ground glass opacity as important findings in the study population and by summarizing the results of studies, it can be concluded that peripheral distribution is the most common finding in these patients.

Author contributions Hadi Majidi: study design, data collection, writing of the paper, final approval. Elham-Sadat Bani-Mostafavi: data collection, writing of the paper, final approval. Zahra Mardanshahi: data collection, writing of the paper, final approval. Fanaz Godazandeh: data collection, writing of the paper, final approval. Roya Gasemian: data collection, writing of the paper, final approval. Keyvan Heydari: data collection, writing of the paper, final approval. Reza Alizadeh-Navaei: study design, data analysis, writing of the paper, final approval.

\section{Compliance with ethical standards}

Ethics declarations The study protocol was approved by the Ethics Committee of Mazandaran University of Medical Sciences (IR.MAZUMS.REC.1398.1425).

Conflict of interest The authors declare that they have no conflict of interest.

\section{References}

1. Li H, Zhou Y, Zhang M, Wang H, Zhao Q, Liu J (2020) Updated approaches against SARS-CoV-2. Antimicrob Agents Chemother. https://doi.org/10.1128/AAC.00483-20

2. Chung M, Bernheim A, Mei X, Zhang N, Huang M, Zeng X, Cui J, Xu W, Yang Y, Fayad ZA, Jacobi A, Li K, Li S, Shan H (2020) CT imaging features of 2019 novel coronavirus (2019-nCoV). Radiology. 295(1):202-207. https://doi.org/10.1148/radiol. 2020200230

3. Lu R, Zhao X, Li J, Niu P, Yang B, Wu H, Wang W, Song H, Huang B, Zhu N, Bi Y, Ma X, Zhan F, Wang L, Hu T, Zhou H, Hu Z, Zhou W, Zhao L, Chen J, Meng Y, Wang J, Lin Y, Yuan J, Xie Z, Ma J, Liu WJ, Wang D, Xu W, Holmes EC, Gao GF, Wu G, 
Chen W, Shi W, Tan W (2020) Genomic characterisation and epidemiology of 2019 novel coronavirus: implications for virus origins and receptor binding. Lancet 395(10224):565-574. https://doi. org/10.1016/S0140-6736(20)30251-8

4. Zhu N, Zhang D, Wang W, Li X, Yang B, Song J, Zhao X, Huang B, Shi W, Lu R, Niu P, Zhan F, Ma X, Wang D, Xu W, Wu G, Gao GF, Tan W, China Novel Coronavirus Investigating and Research Team (2020) A novel coronavirus from patients with pneumonia in China, 2019. N Engl J Med 382(8):727-733. https://doi.org/10. 1056/NEJMoa2001017

5. Su S, Wong G, Shi W, Liu J, Lai AC, Zhou J et al (2016) Epidemiology, genetic recombination, and pathogenesis of coronaviruses. Trends Microbiol 24(6):490-502. https://doi.org/ 10.1016/j.tim.2016.03.003

6. Cui J, Li F, Shi Z-L (2019) Origin and evolution of pathogenic coronaviruses. Origin and evolution of pathogenic coronaviruses. Nat Rev Microbiol 17(3):181-192. https://doi.org/10.1038/s41579018-0118-9

7. Chan JF-W, Yuan S, Kok K-H, To KK-W, Chu H, Yang J et al (2020) A familial cluster of pneumonia associated with the 2019 novel coronavirus indicating person-to-person transmission: a study of a family cluster. Lancet. 395(10223):514-523. https://doi.org/10. 1016/S0140-6736(20)30154-9

8. Rodriguez-Morales AJ, Cardona-Ospina JA, Gutiérrez-Ocampo E, Villamizar-Peña R, Holguin-Rivera Y, Escalera-Antezana JP, Alvarado-Arnez LE, Bonilla-Aldana DK, Franco-Paredes C, Henao-Martinez AF, Paniz-Mondolfi A, Lagos-Grisales GJ, Ramírez-Vallejo E, Suárez JA, Zambrano LI, Villamil-Gómez WE, Balbin-Ramon GJ, Rabaan AA, Harapan H, Dhama K, Nishiura H, Kataoka H, Ahmad T, Sah R, Latin American Network of Coronavirus Disease 2019-COVID-19 Research (LANCOVID-19) (2020) Clinical, laboratory and imaging features of COVID-19: a systematic review and meta-analysis. Travel Med Infect Dis 101623:101623. https://doi.org/10.1016/j.tmaid.2020. 101623

9. Guan W-j, Ni Z-y, Hu Y, Liang W-h, Ou C-q, He J-x, et al (2020) Clinical characteristics of coronavirus disease 2019 in China. N Engl J Med. https://doi.org/10.1056/NEJMoa2002032

10. Wu J, Liu J, Zhao X, Liu C, Wang W, Wang D, et al (2020) Clinical characteristics of imported cases of COVID-19 in Jiangsu province: a multicenter descriptive study. Clin Infect Dis. ciaa199. https://doi. org/10.1093/cid/ciaa199

11. Xie C, Jiang L, Huang G, Pu H, Gong B, Lin H, Ma S, Chen X, Long B, Si G, Yu H, Jiang L, Yang X, Shi Y, Yang Z (2020) Comparison of different samples for 2019 novel coronavirus detection by nucleic acid amplification tests. Int J Infect Dis 93:264-267. https://doi.org/10.1016/j.ijid.2020.02.050

12. Ai T, Yang Z, Hou H, Zhan C, Chen C, Lv W, Tao Q, Sun Z, Xia L (2020) Correlation of chest CT and RT-PCR testing in coronavirus disease 2019 (COVID-19) in China: a report of 1014 cases. Radiology. 200642:200642. https://doi.org/10.1148/radiol. 2020200642

13. Sun D, Li H, Lu XX, Xiao H, Ren J, Zhang FR, Liu ZS (2020) Clinical features of severe pediatric patients with coronavirus disease 2019 in Wuhan: a single center's observational study. World J Pediatr 16:251-259. https://doi.org/10.1007/s12519-020-00354-4

14. Wu J, Wu X, Zeng W, Guo D, Fang Z, Chen L, Huang H, Li C (2020) Chest CT findings in patients with corona virus disease 2019 and its relationship with clinical features. Investig Radiol 55:257261. https://doi.org/10.1097/rli.0000000000000670

15. Li Y, Xia L (2020) Coronavirus disease 2019 (COVID-19): role of chest $\mathrm{CT}$ in diagnosis and management. AJR Am J Roentgenol 214:1280-1286. https://doi.org/10.2214/AJR.20.22954

16. Ye Z, Zhang Y, Wang Y, Huang Z, Song B (2020) Chest CT manifestations of new coronavirus disease 2019 (COVID-19): a pictorial review. Eur Radiol. https://doi.org/10.1007/s00330-02006801-0

17. Bai HX, Hsieh B, Xiong Z, Halsey K, Choi JW, Tran TML, Pan I, Shi LB, Wang DC, Mei J, Jiang XL, Zeng QH, Egglin TK, Hu PF, Agarwal S, Xie F, Li S, Healey T, Atalay MK, Liao WH (2020) Performance of radiologists in differentiating COVID-19 from viral pneumonia on chest CT. Radiology. 200823:200823. https://doi. org/10.1148/radiol.2020200823

18. Chung $\mathrm{M}$ (2020) CT imaging features of 2019 novel coronavirus (2019-nCoV). Radiology. 295(1):202-207. https://doi.org/10. 1148/radiol.2020200463

19. Guan CS, Lv ZB, Yan S, Du YN, Chen H, Wei LG, et al (2020) Imaging features of coronavirus disease 2019 (COVID-19): evaluation on thin-section CT. Acad Radiol. https://doi.org/10.1016/j. acra.2020.03.002

20. Han R, Huang L, Jiang H, Dong J, Peng H, Zhang D (2020) Early clinical and CT manifestations of coronavirus disease 2019 (COVID-19) pneumonia. AJR Am J Roentgenol:1-6. https://doi. org/10.2214/AJR.20.22961

21. Liu H, Liu F, Li J, Zhang T, Wang D, Lan W (2020) Clinical and CT imaging features of the COVID-19 pneumonia: Focus on pregnant women and children. J Infect. 2020. https://doi.org/10.1016/j. jinf.2020.03.007

22. Liu KC, Xu P, Lv WF, Qiu XH, Yao JL, Gu JF, Wei W (2020) CT manifestations of coronavirus disease-2019: a retrospective analysis of 73 cases by disease severity. Eur J Radiol 126:108941. https:// doi.org/10.1016/j.ejrad.2020.108941

23. Shi H, Han X, Jiang N, Cao Y, Alwalid O, Gu J, Fan Y, Zheng C (2020) Radiological findings from 81 patients with COVID-19 pneumonia in Wuhan, China: a descriptive study. Lancet Infect Dis 20(4):425-434. https://doi.org/10.1016/S1473-3099(20) 30086-4

24. Xu X, Yu C, Qu J, Zhang L, Jiang S, Huang D, Chen B, Zhang Z, Guan W, Ling Z, Jiang R, Hu T, Ding Y, Lin L, Gan Q, Luo L, Tang X, Liu J (2020) Imaging and clinical features of patients with 2019 novel coronavirus SARS-CoV-2. Eur J Nucl Med Mol Imaging 47(5):1275-1280. https://doi.org/10.1007/s00259-02004735-9

25. Zhao W, Zhong Z, Xie X, Yu Q, Liu J (2020) Relation between chest $\mathrm{CT}$ findings and clinical conditions of coronavirus disease (COVID-19) pneumonia: a multicenter study. AJR Am J Roentgenol 214:1-6. https://doi.org/10.2214/AJR.20.22976

26. Zhu W, Xie K, Lu H, Xu L, Zhou S, Fang S (2020) Initial clinical features of suspected coronavirus disease 2019 in two emergency departments outside of Hubei, China. J Med Virol. https://doi.org/ 10.1002/jmv. 25763

27. Li K, Fang Y, Li W, Pan C, Qin P, Zhong Y, Liu X, Huang M, Liao Y, Li S (2020) CT image visual quantitative evaluation and clinical classification of coronavirus disease (COVID-19). Eur Radiol. https://doi.org/10.1007/s00330-020-06817-6

28. Song F, Shi N, Shan F, Zhang Z, Shen J, Lu H, Ling Y, Jiang Y, Shi Y (2020) Emerging 2019 novel coronavirus (2019-nCoV) pneumonia. Radiology. 295(1):210-217. https://doi.org/10.1148/radiol. 2020200274

29. Zhou S, Wang Y, Zhu T, Xia LCT features of coronavirus disease 2019 (COVID-19) pneumonia in 62 patients in Wuhan, China. AJR Am J Roentgenol 2020:1-8. https://doi.org/10.2214/AJR.20.22975

30. Yoon SH, Lee KH, Kim JY, Lee YK, Ko H, Kim KH et al (2020) Chest radiographic and CT findings of the 2019 novel coronavirus disease (COVID-19): analysis of nine patients treated in Korea. Korean J Radiol 21(4):494-500. https://doi.org/10.3348/kjr.2020. 0132

Publisher's note Springer Nature remains neutral with regard to jurisdictional claims in published maps and institutional affiliations. 


\section{Figures}

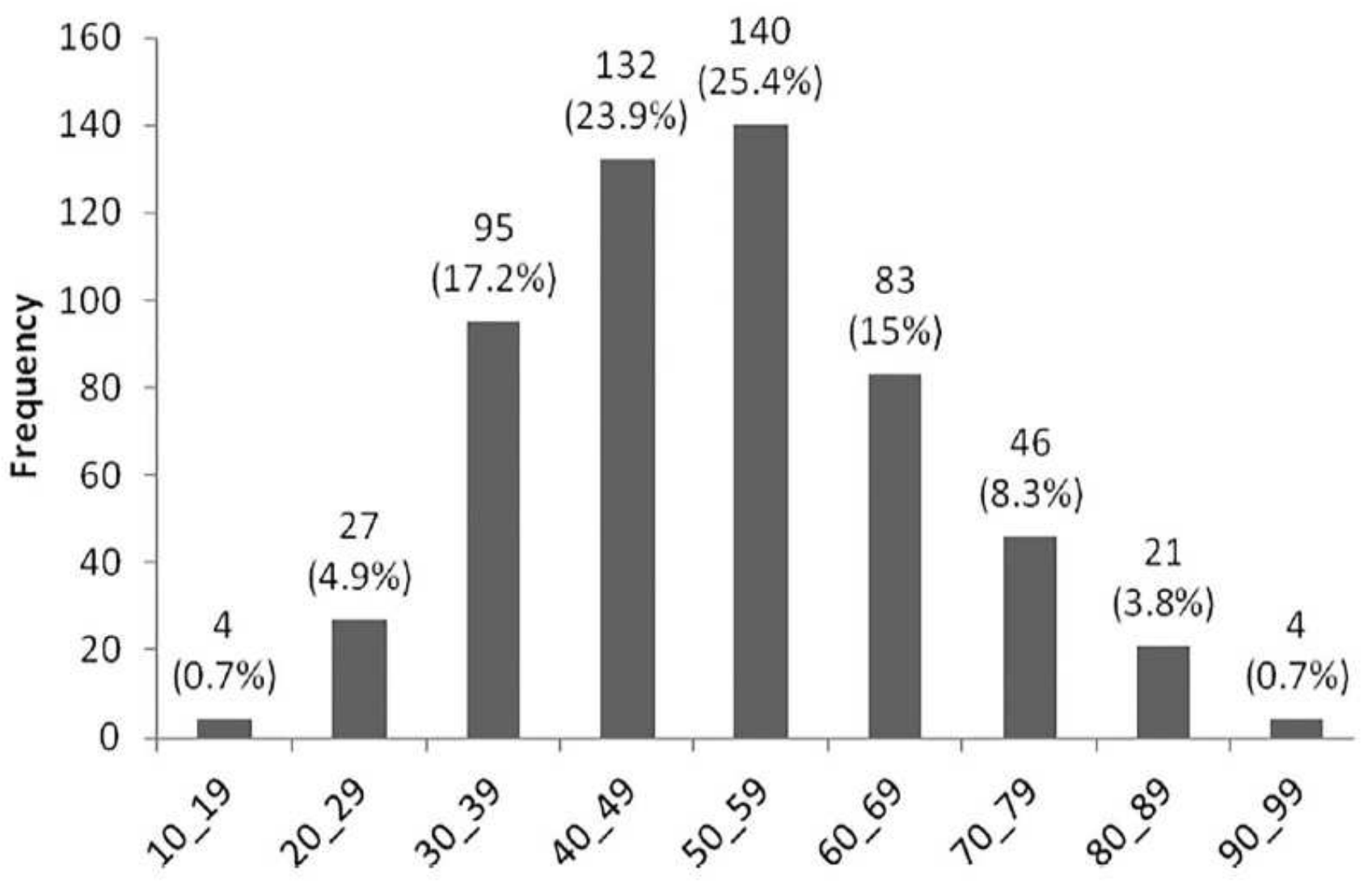

Figure 1

Age distribution of patients with coronavirus 2019 


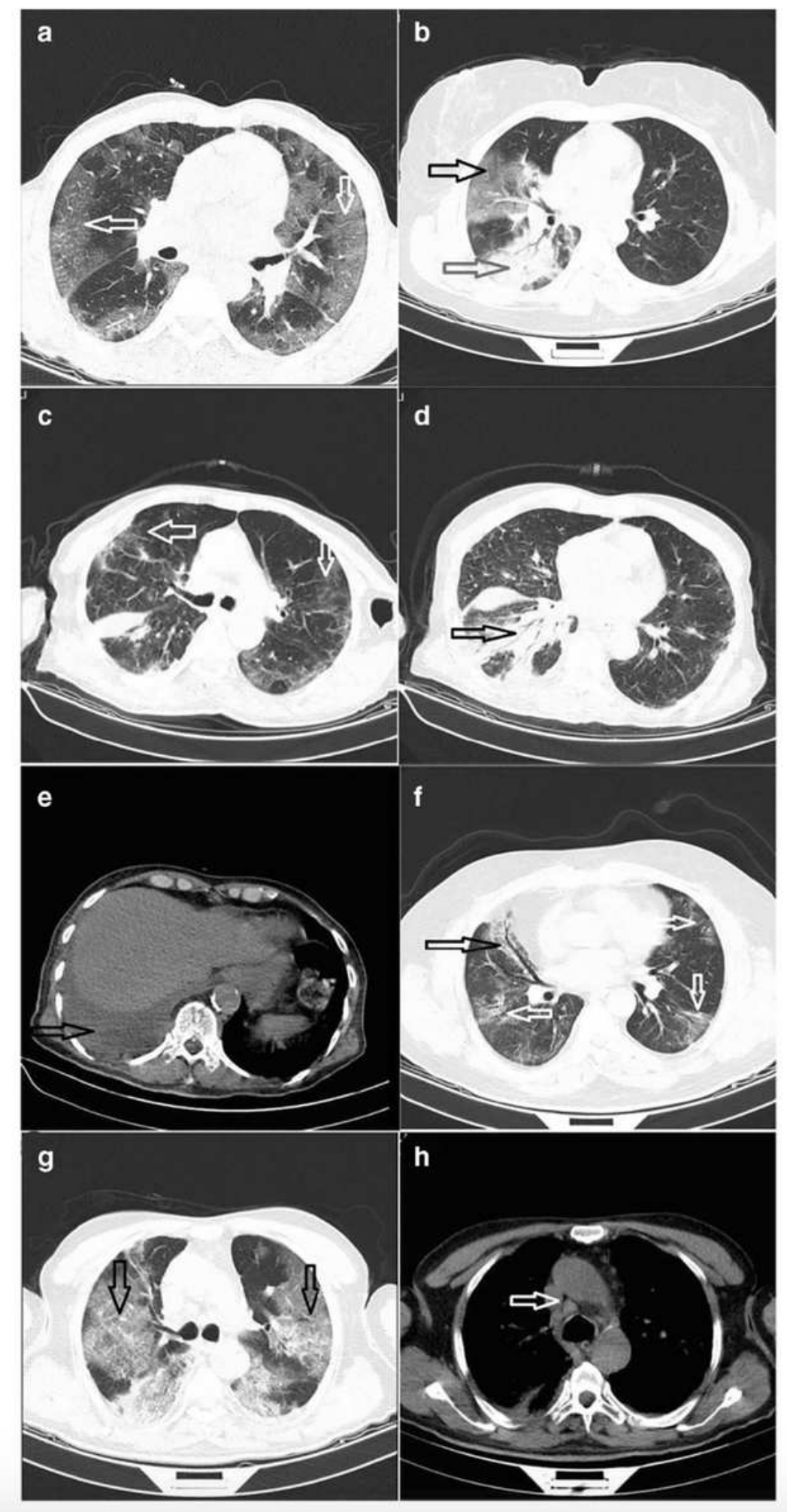

Figure 2

a Bilateral and anterior to posterior peripheral ground glass opacities (white arrows). b Ground glass opacity in upper lobe (black arrow) and consolidation in lower lobe of right lung (red arrow). c Bilateral and peripheral ground glass opacities (white arrows). d Consolidation in right lower lobe (black arrow). e Right-sided pleural effusion (red arrow). f Bilateral and anterior to posterior peripheral ground glass opacities (white arrows) with peribronchovascular distribu- tion in right middle lobe (black arrow). $\mathrm{g}$ 
Bilateral and anterior to poste- rior peripheral ground glass opacities (black arrows). h Small lymphadenopathies in middle mediastinum (white arrow) 